\title{
What is the potential for biogas digesters to improve soil carbon sequestration in Sub-Saharan Africa? Comparison with other uses of organic residues
}

\author{
Jo Smith ${ }^{a *}$, Assefa Abegaz ${ }^{b}$, Robin Matthews ${ }^{c}$, Madhu Subedi ${ }^{c}$, Bob Orskov ${ }^{c}$, \\ Vianney Tumwesige ${ }^{\mathrm{d}}$, Pete Smith $^{\mathrm{a}}$ \\ a Institute of Biological \& Environmental Science, University of Aberdeen, 23 St Machar Drive, \\ Aberdeen, AB24 3UU; ${ }^{b}$ Addis Ababa University, Department of Geography \& Environmental Studies, \\ Addis Ababa, Ethiopia; ${ }^{c}$ The James Hutton Institute, Craigiebuckler, Aberdeen, UK AB15 8QH; ${ }^{d}$ \\ Centre for Research in Energy and Energy Conservation, Makerere University, Kampala, Uganda
}

*Corresponding author: Jo Smith, University of Aberdeen, 23 St Machar Drive, Aberdeen, AB24 $3 U$ U, UK. Tel: (+44) 1224 272702. Fax: (+44) 1224 272703. Email: jo.smith@abdn.ac.uk.

\section{ABSTRACT}

Using bioslurry from anaerobic digestion as an organic fertilizer has great potential to increase carbon sequestration by supplying organic matter to the soil. This paper examines this potential in SubSaharan Africa compared to other uses of organic residues, including burning on pyrolysis cookstoves and composting. Measurements of loss of carbon on treatment of organic residues indicate that the proportion of carbon lost from organic residue during treatment is greater for anaerobic digestion than for aerobic composting or pyrolysis. The stability of organic residue is increased by treatment, and is similar for composted and anaerobically digested material, but is higher for material treated by pyrolysis. Simulations using the RothC model, driven by parameters based on incubations of the organic residues with soil, suggest that on the basis of decomposability alone, treated organic residues sequester significantly more carbon than untreated organic residues, and despite the differences observed in stability, unless biochar contains a high proportion of inert organic material that does not decompose at all, the potential carbon sequestration by incorporating biochar is similar to that for compost or bioslurry. However, if losses of carbon during treatment are also taken into account, incorporating bioslurry sequesters only approximately the same amount of carbon as if the organic residue had been left untreated. By contrast, incorporating compost and biochar sequesters significantly more carbon than incorporating the untreated organic residue. Therefore using bioslurry as an organic fertilizer sequesters less of the carbon in the soil from organic residue than burning on pyrolysis cook-stoves or composting.

\section{Keywords}

Biogas

Soil carbon sequestration

Sub-Saharan Africa

Anaerobic digestion

RothC

\section{Abbreviations}

$\mathrm{C}=$ Carbon

$\mathrm{CH}_{4}=$ Methane

$\mathrm{CO}_{2}=$ Carbon dioxide

DPM = Decomposable plant material

HUM = Humus

IOM = Inert organic matter

$\mathrm{N}=$ Nitrogen

$\mathrm{N}_{2} \mathrm{O}=$ Nitrous oxide

$\mathrm{P}=$ Phosphorus

RothC $=$ Rothamsted Carbon Model 
RPM = Resistant plant material

SSA = Sub-Saharan Africa 


\section{Introduction}

The soils of Sub-Saharan Africa (SSA) are often deficient in soil organic matter and have great potential to sequester carbon (C) [1]. Lal [1] identified SSA as a global hotspot of soil degradation with a high priority for soil restoration and $\mathrm{C}$ sequestration. It has been suggested that a critical limit for soil organic C concentration in most soils of the tropics is $1.1 \%$ [2] (equivalent to $11 \mathrm{~g} \mathrm{~kg}^{-1}$ of dry soil). However, Nyamangara [3] indicated that on average in SSA, the organic C content of soils is less than $1 \%$. Different local studies reveal similar results. For instance, Assefa and van Keulen [4] reported organic $C$ contents between 0.9 and $1.1 \%$ on continuously cultivated soil of the north highlands of Ethiopia. At the same time, solid organic waste removal from urban areas has become an ecological problem in SSA. In a review of the average solid waste generation rate in 23 developing countries, Troschinetz and Mihelcic [5] quantified the average solid organic waste generation by each person to be $770 \mathrm{~g} \mathrm{~d}^{-1}$ and increasing. Biogas digesters have potential to treat this organic waste, greatly increasing the potential for application of organic wastes to soils. If increased recycling of organic wastes can be achieved through implementation of biogas digesters and application of the bioslurry produced, this could have a profound impact on $\mathrm{C}$ sequestration in the region.

Africa is one of the most vulnerable regions to climate change and climate variability in the world [6], and the IPCC recognizes that agricultural production and food security is likely to be severely impacted by climate change in many African countries [6]. Increased temperatures, more frequent droughts and floods, and increased climatic variability are all expected [7]. A significant proportion of the historical increases in soil temperature are attributed to losses of soil organic C. Globally, losses of soil organic $C$ due to human disturbance are estimated to have contributed $11-35 \mathrm{~cm}^{3} \mathrm{~m}^{-3}$ to the atmospheric carbon dioxide $\left(\mathrm{CO}_{2}\right)$ concentration from 1850 to 2000 [7], which in turn equates to a temperature increase of about $0.7^{\circ} \mathrm{C}$ [8]. Widespread installation of biogas digesters could reduce greenhouse gas emissions by reducing $C$ losses due to deforestation [9] and increasing $C$ sequestration in the soil, both directly by increased $C$ inputs and indirectly by increased plant inputs due to improved growth [10]. This, in turn, may help to reduce the contribution of human disturbance to climate change, but whether improved $\mathrm{C}$ sequestration in the soil is actually achieved depends on the alternative uses of the organic residues.

The rate of loss of soil organic matter tends to increase with increased temperature and moisture content of the soil, up to the point where the soil is so hot that micro-organisms cannot function, or the soil is so wet that oxygen supply limits microbial activity [11]. However, the inputs of plant material also tend to increase with temperature and moisture. Whether soils gain or lose $C$ is a balance between increased rates of decomposition and increased plant growth, resulting in higher plant inputs. A global simulation of future changes in soil organic matter using the RothC model [12] predicts that in most regions of SSA, the organic matter content of the soil will increase over the next 100 years due to a climatically induced increase in plant inputs that counteracts the increased rate of loss due to increased temperatures. Only in the grasslands of the south and forest soils converted to arable in central regions is a decrease in soil organic matter due to insufficient gains or reductions in plant inputs predicted [12]. This suggests that these soils are capable of sequestering $C$, and a further increase in organic inputs by the recycling of organic residues could significantly increase the $\mathrm{C}$ content of the soils in SSA.

Organic residues are a limited resource in SSA that are used for a range of different purposes. Traditionally, cattle dung cakes [13,14] and other organic residues [15] have been dried and burnt as a fuel, leaving ash residues that do not greatly enhance the organic matter content of the soil [15]. Another traditional use is as a building material [16]; this application means that none of the C content of the organic residues is returned to the soil in the short term. If this organic residue was instead used to produce biogas, significant increases in $C$ inputs to the soil are likely in addition to the provision of an improved household fuel supply (although the $C$ impacts of replacement building materials should also be considered). However, with other uses, the impacts of diverting the organic residues to biogas production are not so easily determined. All of the $C$ in the organic residues may be incorporated directly in the soil without prior treatment [17]. Organic residues can also be composted under aerobic conditions to provide an important organic fertilizer. A proportion of the organic $\mathrm{C}$ is lost during composting, but when composts are incorporated into the soil, increases in organic matter content are observed [18]. Some types of organic residues can be burnt in pyrolysis stoves or larger scale pyrolysis plants [19]. Pyrolysis occurs when organic materials are burnt under low oxygen conditions $[20,21]$, releasing a proportion of the $\mathrm{C}$ as $\mathrm{CO}_{2}$ or carbon monoxide, but leaving 
a highly resistant form of $\mathrm{C}$, known as biochar, which can be further combusted or incorporated into the soil [22]. When biochar is incorporated into the soil, it is resistant to decomposition, and so sequesters C. Anaerobic digestion, incorporation of untreated residues, aerobic composting and pyrolysis all have potential to improve $\mathrm{C}$ sequestration by adding organic matter to the soil, but which method sequesters most $C$ ? A direct comparison is needed of the $C$ sequestered using the same quantity and quality of starting material, treated by the different methods. In order to evaluate the potential of biogas digesters to improve soil $C$ sequestration in the SSA, the available evidence for comparing the impacts of different treatments of organic residues on $C$ sequestration will be presented in this paper and used to provide simulations of short and long term $C$ sequestration in the soil.

\section{Use of models to estimate carbon sequestration}

The amount of $C$ sequestered in the soil each year is a balance between the annual $C$ input and the annual emissions from the decomposing organic matter. Models that are used to estimate $\mathrm{C}$ sequestration differ in the ways they simulate these two factors.

\subsection{Annual carbon inputs to the soil}

The annual $\mathrm{C}$ input depends on the plant inputs and organic amendments to the soil, but annual plant inputs, especially from dead roots and root exudates, are difficult to measure. Some authors use estimates of plant productivity to determine plant inputs (e.g. Parton et al. [23]); others use the measured $\mathrm{C}$ content of the soil at steady state to infer the plant inputs needed to achieve the measured amount of soil C (e.g. Smith et al. [24]). The amount of C added to the soil in organic residue depends on the treatment process used. Different treatments retain different quantities of $C$ from the same quantity and quality of starting material. The percentage $C$ remaining after treatment of the organic residue is a key parameter that must be determined to allow the amounts of $\mathrm{C}$ sequestered by the different treatments to be compared.

\subsection{Annual carbon emissions from the soil}

The annual emissions of $\mathrm{C}$ from decomposing organic matter depend on the total amount and decomposability of organic matter already present in the soil, the amount and decomposability of any added plant material and organic residues, and the microbial activity, which is dependent of the added organic matter and environmental characteristics (including temperature, water and clay content) of the soil. Some models define decomposability using the decomposition profile for the particular type of organic matter (e.g. Bosatta and Ågren [25]); but this approach can become unwieldy when many different types of organic materials are added to the soil on numerous occasions. Other models define decomposability by quantifying the proportions of "decomposable" and "resistant" fresh plant material, and "rapidly" and "slowly" decomposing organic material for the organic matter already present in the soil and the organic matter added as plant inputs and organic amendments (e.g. Coleman and Jenkinson [26]). The rate constants set for these different pools allow the proportions of the different pools to define the decomposition profile without the need to keep track of each different amendment of organic material.

\subsection{Decomposability of organic residues}

The decomposability of the organic residue following treatment is another key parameter that must be determined to allow the potential for $\mathrm{C}$ sequestration by different treatments to be compared. Most composting models predict the evolution of dry mass, temperature, moisture, oxygen and $\mathrm{CO}_{2}$, but not the decomposability of the organic matter following treatment [27]. Some models have recently been published that describe the evolution of organic matter quality during composting. These models function in the same way as the soil organic matter models, dividing the organic matter into pools with specific decomposition rates. Tremier et al. [28] used easily and slowly decomposable fractions, setting the percentage of the pools using experimental oxygen uptake rates. Sole-Mauri et al. [29] divided the organic matter into 6 pools (carbohydrates, proteins, lipids, hemicelluloses, cellulose and lignin), and evaluated the model against the evolution of temperature, $\mathrm{C}$ content and mineral $\mathrm{N}$. Zhang et al. [30] developed a model that describes the evolution of the biochemical composition of organic matter and reflects its potential degradability in soil after application. First-order kinetics have been most widely used to describe the decomposition of treated and untreated organic residues $[31,32,33,34]$, although different order equations have been used by some authors (e.g. Bernal and 
Kirchmann [35]).

Models of anaerobic digestion are less well developed than composting models due to the complexity of the process and smaller amount of experimental evidence available on the processes of anaerobic digestion [36]. Most of these models do not quantify the decomposability of the bioslurry, focusing more on biogas production [37]. Each component of the organic residue (carbohydrates, proteins and lipids) goes through three stages of decomposition; hydrolysis, fermentation and methane $\left(\mathrm{CH}_{4}\right)$ production. When considering solid residue digestion, hydrolysis of the complex polymeric substances is often considered to be the rate-limiting step [38]. Fermentation of amino acids, sugars and fatty acids is done by fermentative or acid-forming bacteria, which use extra-cellular enzymes to break down the carbohydrates, proteins and lipids into soluble sugars, amino acids and fatty acids, respectively, forming organic acids, hydrogen and $\mathrm{CO}_{2}$ [39]. Hydrogen producing acetogenic bacteria complete the fermentation by oxidizing fatty acids to produce acetic acid, hydrogen and $\mathrm{CO}_{2}[40]$. Approximately $75 \%$ of $\mathrm{CH}_{4}$ production is done by acetoclastic methanogens, which transform acetic acid to methane and $\mathrm{CO}_{2}$, and $25 \%$ by $\mathrm{H}_{2}$ utilizing methanogens, which reduce $\mathrm{CO}_{2}$ to $\mathrm{CH}_{4}$ [41]. Early modeling approaches attempted to simplify the description of this complex set of processes by describing only the rate limiting step [42]. The limiting factors can, however, be different under different operating conditions [43], resulting in different authors focusing on different rate limiting steps; $\mathrm{CH}_{4}$ production from acetic acid, conversion of fatty acids into acetic acid, and hydrolysis of suspended solids [44]. The concentration of volatile fatty acids soon emerged as a key parameter [45], with formation of volatile fatty acids and their conversion to acetic acid being described separately [46]. The influence of ammonium- $\mathrm{N}$ on $\mathrm{CH}_{4}$ production [42] and the controlling inhibiting role of hydrogen gas in the formation of volatile fatty acids and subsequent conversion into acetic acid $[47,48]$ were also included in models. This gave rise to models that predict the change in individual volatile fatty acid species, $\mathrm{pH}$, partial pressure of hydrogen gas, and biogas production and composition as a function of time [36,49,50,51]. In an attempt to produce a generic model and reach a common basis for further development, Batstone et al. [52] included descriptions of the dynamics of 24 species and 19 bioconversion processes. Such complexity makes the model very difficult to use, and an additional step would be required to translate the values simulated into a description of decomposability of bioslurry.

Until recently, models of biochar decomposability were limited to conceptual models due to lack of data for parameterization. Hammes et al. [53] suggested that decomposability of biochar in soils should be simulated using multiple pool models. Nguyen et al. [54] described decomposition of "black carbon" remaining after fire using a two pool model, one pool decomposing over decades and the other being inert. Foereid et al. [55] suggested the inert pool is in fact slowly decomposing and so instead included a slowly decomposing pool containing $88 \%$ of the biochar with a decomposition rate constant of $1.37 \times 10^{-6} \mathrm{~d}^{-1}$. The remaining $12 \%$ of the biochar $C$ was in a labile pool with a rate constant of $0.0038 \mathrm{~d}^{-1}$. While this provides a very neat description of biochar decomposition that is compatible with existing soil organic matter models, further work is needed to account for the impact of feedstock and production conditions on the decomposability of the biochar produced.

\section{Loss of carbon on treatment of organic residues}

\subsection{Aerobic composting}

Composting of organic residues significantly reduces the $C$ content of the material. Ciavatta et al. [56] observed a $30 \%$ loss of $\mathrm{C}$ during 2 months of composting of municipal solid waste. Most of the C losses during composting occur during the initial active phase. On composting of organic residues under controlled conditions, Bernal et al. [17] observed $37-60 \%$ of initial $\mathrm{C}$ was mineralized during the initial active phase, with $C$ release increasing to $52-74 \%$ during later phases of composting. This suggests that, in this case, $26-48 \%$ of the $C$ contained in the untreated organic residue remains in the composted material (Table 1). Bernal et al. [17] noted that a high ratio of lignin to cellulosic compounds is associated with a lower loss of $\mathrm{C}$ through mineralization during composting. Further losses of $\mathrm{C}$ as $\mathrm{CH}_{4}$ may also occur due to the coexistence of anaerobic and aerobic conditions especially in large, extensively managed compost heaps [57].

\subsection{Anaerobic digestion}

The conversion of organic $\mathrm{C}$ to $\mathrm{CH}_{4}$ is a very efficient process. As a result, the reduction in total $\mathrm{C}$ on anaerobic digestion was observed to be $71 \%$ by Massé et al. [58], $69-80 \%$ in a series of experiments 
by Schievano et al. [59], and $94 \%$ by Perez et al. [60], although the latter used thermophilic digestion so may not be relevant here. The $20-31 \%$ of the total organic $C$ that is not lost $([58,59]$; Table 1$)$ remains in the bioslurry and is usually composed of material that is not readily available to biological degradation [61].

\subsection{Pyrolysis}

As much as $50 \%$ of the C contained in the source material can be retained within the biochar produced by pyrolysis, but this is highly dependent on the specific conditions of the process $[62,63,64,65,66]$, especially the temperature [67]. Bruun et al. [68] observed $50 \% \mathrm{C}$ retained as biochar at $475{ }^{\circ} \mathrm{C}$, but only $20 \%$ at $575{ }^{\circ} \mathrm{C}$ (Table 1). The temperature also affects the nature of the material contained in the biochar. Yang et al. [69] observed that at temperatures of $475{ }^{\circ} \mathrm{C}$, low heating rate processes (slow pyrolysis) converted nearly all carbohydrates to volatile substances, whereas Bruun et al. [68] observed an unconverted biomass fraction remaining after fast pyrolysis due to heat transfer limitations. These were composed of cellulosic and hemi-cellulosic compounds and were proportional to short-term biochar degradation in soil, which resulted in $3-12 \%$ of the added biochar being rapidly emitted as $\mathrm{CO}_{2}$. Increasing the temperature of pyrolysis decreased the proportion of labile material in the biochar to close to zero, but also increased the proportion of total C lost on pyrolysis [68].

Table 1 here

\section{Decomposability of organic residues in soil}

\subsection{Fresh organic residues}

The amount of $C$ released when fresh organic residues are incorporated in the soil differs with the type of organic residue [34]. Incorporation of residues that contain a high proportion of soluble organic $\mathrm{C}$, for instance in the form of amino acids and carbohydrates, tends to result in a flush of $\mathrm{CO}_{2}$ release immediately after incorporation [70]. By contrast, residues, such as sweet sorghum bagasse, containing a high proportion of resistant materials, can show very low initial decomposition rates. In experiments on the release of organic $C$ from untreated and treated organic residues, Bernal et al. [17] observed losses of $C$ in the range of $21-62 \%$ for untreated plant materials and animal manures after 30 days incubation in soil, in agreement with the observations of Ajwa and Tabatabai [34], and even higher losses for mixtures including sewage sludge and city refuse (93\% and $80 \%$ respectively). After 140 days of incubation, Bernal et al. [17] observed that in most untreated organic residues, C losses range from $95 \%$ to over $100 \%$ (Table 2). Such high losses suggest that most of the organic material is in a highly decomposable form. Losses over $100 \%$ imply a priming effect due to the stimulated microbial activity in the soil, which increases decomposition of the native soil organic matter and so actually results in a net loss of $C$ from the soil. This may well also be occurring in the experiments showing lower percentage loss and is subsumed into the overall value for the change in soil C.

\subsection{Composts}

Treatment of organic residues changes their composition [18], and so also the decomposability and release of $\mathrm{CO}_{2}$ on incorporation in the soil [35]. The decomposability of composts is dependent on the biochemical characteristics of the compost after treatment. Amír et al. [70] showed that the decomposition of sludge during composting begins with lipid, protein and carbohydrate components. Experimental studies on the decomposability of different mixtures of organic materials have shown that the evolution of decomposability is a function of initial composition and biochemical properties [71,72]. Bernal et al. [17] suggested that a high ratio between lignin and cellulosic compounds in composts confers greater stability to the compost. The $\mathrm{CO}_{2}$ released on incubating mature composts with soils for 30 days decreases with time of composting, with $\mathrm{C}$ released from mature composts usually being less than $25 \%$ of the $C$ in the compost $[17,73,74]$ compared to $21-62 \%$ when fresh residues are applied [17]. After 140 days of incubation with soil, Bernal et al. [17] observed a much lower total loss of $\mathrm{C}$ (the sum of losses during both composting and incubation in the soil) from mature composts than from untreated organic residues, total C losses ranging from $64-80 \%$ of the total $\mathrm{C}$ in the initial fresh organic residue lost when compost was applied compared to $95 \%$ to over $100 \%$ when fresh residues were applied. Given that $52-74 \%$ of these losses occurred during composting (Table 1 ), 
the losses after incorporation in the soil were only $6-12 \%$ (Table 2). Therefore, applying mature composts to the soil retains more $\mathrm{C}$ than applying fresh organic residues. However, if composts are applied before maturity at the end of the thermophilic phase, total $C$ losses can be higher even than in untreated residues due to stimulation of the microbial population and addition of a high proportion of labile organic compounds to the soil [17], so it is important that only fully mature and stable composts are applied to the soil.

\subsection{Bios/urry produced by anaerobic digestion}

Treatment of organic residues by anaerobic digestion stabilizes the organic matter and reduces the rate of $\mathrm{CO}_{2}$ emissions when the residues are applied to soils. In soil incubation studies with anaerobic digests of pig slurry, Marcato et al. [75] observed a significantly higher $\mathrm{C}$ mineralization rate after 49

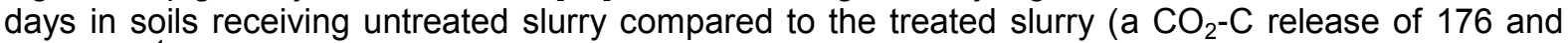
$120 \mathrm{~g} \mathrm{~kg}^{-1}$ organic $C$ supplied respectively). These rates were similar to those reported by GarćiaGómez et al. [76] for untreated and composted pig slurry $\left(22.5 \mathrm{~g}\right.$ and $12.0 \mathrm{~g} \mathrm{CO}_{2}-\mathrm{C} 100 \mathrm{~g}^{-1}$ organic C supplied respectively), suggesting that the decomposability of organic matter following 7 weeks of anaerobic digestion is similar to the decomposability following 4 weeks of composting. Therefore, in Table 2, the decomposability of bioslurry is described similarly to composts.

Messner and Amberger [61] suggested that $C$ not transformed into biogas during anaerobic digestion is mainly composed of materials that are less available for biological degradation. Fourier transform infrared spectroscopy was used by Marcato et al. [75] to characterize the functional groups in the raw and digested slurry. The raw and digested slurry contained similar functional groups, but showed a marked decrease in aliphatic structures and lipids, amides and polysaccharides, representing the biodegradation of the labile fraction into biogas with a relative increase in the more resistant and stable compounds [77]. This is consistent with the initial decomposition of lipids, proteins and carbohydrates observed during aerobic composting by Amír et al. [70]. An increase in carbonates was observed, and Marcato et al. [75] suggested this was due to mineralization of organic matter during digestion. Comparison of the stabilization of organic matter during biological treatment of municipal organic residues using combined mechanical, anaerobic and composting treatments suggested that stabilization was greatest during the anaerobic digestion [78].

\subsection{Biochar produced by pyrolysis}

Biochar is highly resistant to decomposition due to its aromatic structure $[79,80]$. It is a carbonaceous material, containing polycyclic aromatic hydrocarbons with a range of different functional groups [21]. The time over which biochar incorporated in the soil remains stable is not well known $[53,54,81,82,83,84]$. However, $\mathrm{C}$ dating shows biochar deposits in Terra preta soils in regions within the Amazon-basin are 500 to 6000 years old [85], and the turnover time of biochars has been estimated to be on the timescale of millennia [82]. This is dependent on the environmental conditions; the soil water regime has been shown to modify biochar stability depending on the initial properties of the feedstock used, biochars produced at lower temperatures from more labile feedstocks being less stable than biochars produced at higher temperatures [84].

An unconverted biomass fraction was observed by Bruun et al. [68] to remain after fast pyrolysis. This fraction was composed of highly labile cellulosic and hemi-cellulosic material and was proportional to short-term biochar degradation in soil, which resulted in $3-12 \%$ of the added biochar being rapidly emitted as $\mathrm{CO}_{2}$ (Table 2). There has been some suggestion that labile compounds held in the biochar can have a priming effect on the soil, actually causing native soil organic matter to be released due to increased biological activity. However, Cross and Sohi [86] showed that the extra C mineralization observed following biochar application is due to rapid decomposition of the labile materials in the biochar itself, and not due to additional losses of $\mathrm{C}$ from the soil.

Table 2 here

\section{Changes in carbon sequestration for different uses of organic residues}

A representation of the RothC model [26] using an annual timestep was used to determine the soil C sequestration that might be expected when the same amount of starting material is incorporated in the soil, either as untreated organic residue, or following composting, anaerobic digestion or pyrolysis. 
Typical values for the percentage of $C$ loss on treatment, $P_{\text {loss }}$ (\% untreated organic residue), were used to determine the relative amounts of $\mathrm{C}$ incorporated in the soil, $P_{\text {input }}(\%$ of untreated organic residue), as

$$
P_{\text {input }}=100-P_{\text {lass }}
$$

The relative amounts of $\mathrm{C}$ assumed to be incorporated for the different treatments of organic residues are given in Table 1.

The decomposability of the incorporated organic residue was defined using the proportion of decomposable plant material (DPM) to stabilized material (HUM) in the organic residue. Decomposable and stabilized material are defined as having decomposition rate constants of $10 \mathrm{y}^{-1}$ and $0.02 \mathrm{y}^{-1}$ [26]. Therefore, the ratio of DPM to HUM determines the rate of organic residue decomposition in the soil.

The proportion of $\mathrm{C}$ in the DPM pool, $C_{\mathrm{DPM}}\left(\mathrm{t} \mathrm{ha}^{-1}\right)$, that within the timestep is lost by decomposition as $\mathrm{CO}_{2}-\mathrm{C}, \mathrm{C}_{\mathrm{DPM}, \text { loss }}\left(\mathrm{t} \mathrm{ha}^{-1}\right)$ is given by an exponential equation for first order decomposition [26],

$$
p_{\mathrm{DPM}, \mathrm{ICas}}=\frac{C_{\mathrm{DPM} \text {, Dess }}}{C_{\mathrm{DPM}}}=1-e^{-\mathrm{abc} k \mathrm{DPM} t}
$$

where $a, b$ and $c$ are rate modifying factors for temperature, moisture and plant cover respectively, $k_{\mathrm{DPM}}$ is decomposition rate constant for DPM $\left(k_{\mathrm{DPM}}=10 \mathrm{y}^{-1}\right.$, as given by Coleman and Jenkinson [26]), and $t$ is a factor to convert the annual time step of the rate constant to actual period of incubation ( $t=\frac{d}{365}$, where $d$ (days) is the duration of the incubation).

The temperature rate modifier is given by Coleman and Jenkinson [26],

$$
a=\frac{47.9}{1+\exp \left(\frac{106}{T+18.3}\right)}
$$

where $T$ is the average air temperature over the period of the timestep, $t\left({ }^{\circ} \mathrm{C}\right)$.

The moisture rate modifier $(b)$ is also given by Coleman and Jenkinson [26],

$$
b=0.2+(1.0-0.2) \times \frac{D_{\max }-D}{D_{\max }(1-0.444)}
$$

where $D_{\max }$ is the maximum soil moisture deficit $(\mathrm{mm})$ and $D$ is the actual soil moisture deficit $(\mathrm{mm})$.

The plant cover rate modifier $(c)$ accounts for the impact of factors due to the presence of the plant, such as shading of the soil, on the rate of decomposition. The plant cover rate modifier is set to 0.6 when the plant is present and 1.0 when it is not [26].

Coincidentally, the experiments that were used to determine the decomposability were all incubated at a constant temperature of $28^{\circ} \mathrm{C}$ and maintained $60 \%$ of the field capacity of the soil, giving rate modifiers of $a=4.41$ and $b=0.79$. Because there are no plants included in the incubations, the plant cover rate modifier, $c$, was set to $1.0[26]$.

Similarly, the proportion of $\mathrm{C}$ in the HUM pool, $C_{\mathrm{HUM}}\left(\mathrm{t} \mathrm{ha}^{-1}\right)$ that within the timestep is lost by decomposition as $\mathrm{CO}_{2}-\mathrm{C}, \mathrm{C}_{\mathrm{HUM}, \text { loss }}\left(\mathrm{t} \mathrm{ha}^{-1}\right)$ is given by

$$
p_{\mathrm{HUM}, \mathrm{loss}}=\frac{c_{\mathrm{HUM} \text { Josi }}}{c_{\mathrm{HUM}}}=1-e^{-\mathrm{abc} k_{\mathrm{HUM}} \mathrm{t}}
$$

where the rate constant, $k_{\mathrm{HUM}}$, for decomposition of the HUM pool is $0.02 \mathrm{y}^{-1}$ [26].

Assuming that all of the $C$ in the incorporated organic residue can be described as $C$ in either the 
DPM or HUM pools, the measured percentage loss of incorporated organic residue, $P_{\text {loss }}(\%)$, can be related to the proportions of $\mathrm{C}$ in the DPM and HUM pools lost by decomposition

$$
P_{\text {loss }}=\left(p_{\text {DPM , loss }}+p_{\text {HUM, loss }}\right) \times P_{\text {linput }}
$$

Substituting the equations for $p_{\mathrm{DPM}, \mathrm{loss}}, p_{\mathrm{HUM}, \text { loss }}$ and $P_{\text {input }}$ into the above equation and rearranging allows the proportion of DPM and HUM in the incorporated organic residue ( $p_{\mathrm{DPM}}$ and $p_{\mathrm{HUM}}$ ) to be determined

$$
p_{\text {DPM }}=\frac{\left(P_{\text {loos }} / 100\right)+p_{\text {HUM Joss }}}{P_{\text {DPM Joss }}-p_{\text {HUM , loss }}}
$$

and

$$
p_{\mathrm{HUM}}=1-p_{\mathrm{DPM}}
$$

The DPM/HUM ratios are obtained from ${ }^{p_{\mathrm{DPM}}} / p_{\text {HUM }}$ and are presented in Table 2.

The 140 day incubations of Bernal et al. [17] provide a much higher DPM/HUM ratio for untreated residue $(>18)$ than for compost $(0.04-0.11)$, indicating a higher proportion of decomposable plant material and a more rapid decomposition rate in the untreated compost. For shorter incubations (30 days), the DPM/HUM ratio obtained from Bernal et al. [17] are significantly lower (0.28-1.90) than in the 140 day incubations (18-96), indicating that, in the initial phases of the incubation of the untreated residue, a higher proportion of DPM is being decomposed. Similar results to Bernal et al.'s [17] 30 day incubation are obtained from 49 day incubations of untreated residue provided by Marcato et al. [75] (DPM/HUM = 0.2), suggesting that the experiments of Marcato et al. [75] and Bernal et al. [17] are comparable. The 49 day incubations of composted residue from Marcato et al. [75] show comparable ratios to 140 day incubations of compost from Bernal et al. [17] (DPM/HUM $=0.13$ compared to 0.040.11). This suggests that, unlike the untreated residue, the decomposition of compost already accesses all pools of organic matter after 49 days and so the ratio obtained is likely to reflect the actual proportions of DPM and HUM in the compost. The DPM/HUM ratios obtained from the data of Marcato et al. [75] for bioslurry and compost were very similar ( 0.14 and 0.13 respectively), suggesting the decomposability of compost and bioslurry can be treated similarly. Using the data provided by Bruun et al. [68], the DPM/HUM ratios for biochar are slightly lower than for compost and bioslurry $(0.004-0.11)$. Foereid et al. [55] suggested that biochar is composed of labile and stable pools, and used decomposition rate constants of $0.0038 \mathrm{~d}^{-1}$ (equivalent to $1.387 \mathrm{y}^{-1}$ ) and $1.37 \times 10^{-6} \mathrm{~d}^{-}$ (equivalent to $0.0005 \mathrm{y}^{-1}$ ) respectively. This assumption is compatible with the approach suggested here, and can simulate the data of Bruun et al. [68] using a ratio of the labile/stable pools of 0.0360.16 . However, the chemical characterization of biochar provided by Bruun et al. [68] suggests that biochar should be represented as $3-12 \%$ highly labile material, the remainder being highly stabilized or inert. If this is the case, an alternative representation of biochar is needed in RothC that assumes $88-97 \%$ of the added biochar is inert organic material (IOM), and the remainder as highly labile similar to untreated organic residue (DPM/HUM $>18$ ).

To illustrate the impact of incorporating different types of organic residues on the potential $\mathrm{C}$ sequestration in different soils and climates, a single factor sensitivity analysis was completed for the input variables average annual air temperature, average annual soil water content and percent clay content. The starting values of all input variables are arbitrarily selected typical conditions for SSA and are given in Table 3 . The simulations were continued until a steady state was achieved or for 300 years. One input variable at a time was adjusted between $-50 \%$ and $+50 \%$ of the starting value while holding all other input variables constant. This was done for untreated and treated organic residues, assuming annual $\mathrm{C}$ inputs and DPM/HUM ratios as shown in Table 4. These were selected from the reviewed values given in Tables 1 and 2

Table 3 here

Table 4 here 
The results of the sensitivity analysis applying $1 \mathrm{t} \mathrm{ha}^{-1} \mathrm{y}^{-1}$ of $\mathrm{C}$ in differently treated organic residues are shown in Fig. 1, 2 and 3. The results show that under all conditions of temperature, soil moisture and clay content, incorporating $1 \mathrm{t} \mathrm{ha}^{-1} \mathrm{y}^{-1}$ of $\mathrm{C}$ as treated residue results in significantly higher $\mathrm{C}$ sequestration than incorporating $1 \mathrm{t} \mathrm{ha}^{-1} \mathrm{y}^{-1}$ of $\mathrm{C}$ as untreated residue. The impacts of incorporating compost or bioslurry on $\mathrm{C}$ sequestration are very similar. The impact of incorporating $1 \mathrm{t} \mathrm{ha}^{-1} \mathrm{y}^{-1}$ of $\mathrm{C}$ as biochar depends on the nature of the biochar. If, as suggested by Foereid et al. [55], the biochar is composed of labile and stabilized organic matter (biochar (a)), C sequestered is very similar to the amount sequestered by applying compost or bioslurry. If, however, as suggested might be the case by Bruun et al. [68] and Nguyen et al. [54], the biochar contains a high percentage of IOM (biochar (b)), $\mathrm{C}$ sequestration is significantly increased by incorporating the organic residue as biochar, especially at the higher average air temperatures as found in SSA. Whether the C incorporated as biochar is chemically and biologically inert, or just highly stabilized has a profound impact on the $\mathrm{C}$ sequestered in the soil and merits further research.

\section{Fig.1 here}

Fig.2 here

\section{Fig.3 here}

This accounts for the changes in the decomposability of the organic residue, but does not account for the losses in soil $C$ during the treatment process. The results of the sensitivity analysis applying differently treated organic residues derived from $1 \mathrm{t} \mathrm{ha}^{-1} \mathrm{y}^{-1}$ of $\mathrm{C}$ as fresh organic residue are shown in Fig. 4, 5 and 6 . Now a very different picture is seen. Because a higher proportion of the fresh organic residue has been assumed to be lost during anaerobic digestion (74\%) than during aerobic composting or pyrolysis (63\% and $65 \%$ respectively), all results show C sequestration for incorporation of bioslurry is now not significantly higher than $\mathrm{C}$ sequestered if fresh residue were incorporated. This is further illustrated by the calculation of $C$ sequestered for the default soil and climatic conditions given in Table 3 and using the range of values obtained from the literature describing organic residue quality (DPM:HUM ratio and proportion of IOM) and the proportion of C lost on treatment given in Table 2. These simulations provide an estimate of the uncertainty in the calculation (as shown by the error bars in Fig. 7), and illustrate that while there is a clear difference between the $\mathrm{C}$ sequestered by applying fresh residue compared to compost or biochar, when losses in $\mathrm{C}$ during treatment are accounted for there is no significant difference in applying fresh residue compared to bioslurry. Fig. 8 shows the uncertainty associated with the different inputs, expressed as the percentage change in the $C$ sequestered at the average input value (Tables 3 and 4 ) using the range of inputs values given in Table 4. The amount of $\mathrm{C}$ lost during treatment introduces greater uncertainty in the estimates of $C$ sequestered by applying bioslurry $(50 \%)$ compared to the DPM:HUM ratio $(13 \%)$. The uncertainty in $C$ sequestered by incorporating biochar is very high, ranging from $C$ sequestration that is not significantly different to the value obtained for compost, to a result that is nearly 9 times that (Fig. 7). This is mainly due to uncertainties in the proportion of IOM and C lost during treatment (introducing $151 \%$ and $71 \%$ uncertainty, respectively).

Fig. 4 here

Fig. 5 here

Fig. 6 here

Fig. 7 here

Fig. 8 here

The above results provide an estimate of the potential for $\mathrm{C}$ sequestration if applications of organic residues were continued until steady state conditions were achieved. In reality, incorporation of organic residues is unlikely to continue for so long, and it is perhaps unreasonable to plan for more than 10-20 years into the future. In this case, the rate of $\mathrm{C}$ sequestration becomes more important. As shown in Fig. 9, for simulations using the input variables given in Table 3, the highest rate of $\mathrm{C}$ sequestration over the first 20 years is observed for incorporation of biochar and compost. The greatest difference is seen in the results after organic residue incorporation has ceased. Unless a 
significant proportion of IOM is present in the biochar, all treatments return to close to the initial $\mathrm{C}$ content by 100 years, and very little difference in observed in the $C$ contents of soils receiving the different types of organic residues after this time. The $\mathrm{C}$ sequestration should be considered a temporary measure. However, the period with extra soil organic matter may result in a positive feedback of higher plant inputs that then permanently maintains the soil at a higher $\mathrm{C}$ content. However, if the biochar contains IOM, the soil C content remains close to the higher level over the duration of the simulation.

Fig. 9 here

\section{Discussion}

Data in the literature provides information about the rate of $C$ loss during treatment of organic residues, and the decomposability of the differently treated organic residues when incorporated into soils. Using this information to drive simple dynamic simulations of $\mathrm{C}$ turnover in soils allows the impact of the different treatments on $\mathrm{C}$ sequestration to be estimated. This approach uses a simple incubation method to determine the size of organic matter pools in incorporated organic residues. Because these are only short term measurements, there is potential for the impact of the more recalcitrant pools to have been neglected. This was seen, for example, in the different DPM/HUM ratios obtained for the same untreated organic residue after 30 days and 140 days; the 30 day incubation has a much lower DPM/HUM ratio than the 140 day incubation because only part of the DPM fraction had been accessed after the shorter period (Table 2). Incomplete access to the different organic matter pools by the soil micro-organisms might especially introduce error for organic residues with more recalcitrant organic pools, such as biochar. This suggests the need for evaluation of the results against short, medium and long term experimental data. Having used the method presented here to provide an initial estimate for the DPM/HUM ratio, the value can be adjusted against long term experimental data to provide a more accurate estimate of long term $C$ sequestration, which can then be re-evaluated against independent data.

The impact of organic amendments on the activity of the micro-organisms in the soil is not explicitly described in the RothC model. Therefore, the impact of differently treated organic residues on microbial activity cannot be explicitly quantified through this approach. However, this is implicitly included in the incubation measurements used to obtain the parameters for the different types of organic residues. Therefore, the results do implicitly account for any differences in microbial activity that may occur following application of differently treated organic residues.

The simulations presented above suggest that if the loss of $C$ during treatment of organic residues is not accounted for, incorporating any of the treated organic residues will sequester more $C$ than incorporating the same quantity of organic residue before treatment. However, when $\mathrm{C}$ loss during treatment is accounted for, incorporating bioslurry sequesters only approximately the same amount of $\mathrm{C}$ as if the organic residue had been left untreated. By contrast, incorporating compost and biochar sequesters significantly more $C$ than incorporating the untreated organic residue. The numbers presented here suggest that the low $C$ sequestration associated with bioslurry is due to the highly efficient anaerobic decomposition process, which converts a high proportion of the $\mathrm{C}$ in the organic residue into $\mathrm{CH}_{4}$, resulting in a large proportion of the $\mathrm{C}$ being lost from the remaining organic residue. Treatment by composting and pyrolysis lose a lower proportion of the $C$ than treatment by anaerobic digestion, resulting in higher $\mathrm{C}$ sequestration when incorporated in the soil. Measurements of $\mathrm{C}$ losses during treatment are highly dependent on the conditions of the treatment, and trends in $C$ sequestered by the different methods could easily be reversed if the conditions of treatment were changed. This suggests the need for further research to optimize the potential for $C$ sequestration from different treatments, although any adaptation to retain more $C$ in the bioslurry is likely to reduce the yield of methane, and so would be counterproductive.

There is also a high degree of uncertainty around the stability of the organic material remaining in biochar. If a high proportion of the organic matter in the biochar is inert, incorporating biochar has potential to sequester significantly more $\mathrm{C}$ than incorporating either compost, bioslurry or untreated residue, and to retain $\mathrm{C}$ after incorporation of organic residues has stopped, whereas if a very low proportion of the organic matter is inert, incorporated biochar behaves very similarly to incorporated compost. This could suggest that the best way to sequester $\mathrm{C}$ originating from organic residues in the soil is to incorporate biochar. However, organic residues also provide nutrients, impacting crop 
productivity. This can in turn significantly affect inputs of $C$ to the soil from plant residues. Smith et al. [10] suggest that the process of pyrolysis burns off a high proportion of the nutrients in organic residues, so reducing the positive impact on crop production in a nutrient limited soil, the optimum return of nutrients being achieved through incorporation of compost or bioslurry. Further research is needed to provide a better understanding of the stability of organic material remaining in biochar as this has a profound impact on the efficacy of $\mathrm{C}$ sequestration.

\section{Conclusions}

Incorporating compost sequesters more $\mathrm{C}$ than incorporating bioslurry, as well as providing similar returns of nutrients. However, composting does not provide an easily captured source of household energy, so a major benefit of recycling organic residues will be missed by composting alone. Incorporating biochar sequesters more $\mathrm{C}$ than bioslurry, as well as providing household energy, but the nutrients in the organic residue may be burnt off, so reducing the availability of much needed nutrients to the crop. Perhaps the optimum management of organic residues for $\mathrm{C}$ sequestration and energy production involves a combination of anaerobic digestion and pyrolysis. Anaerobic digestion can provide a quick release source of nutrients, which can improve crop productivity and maintain $\mathrm{C}$ inputs from plant residues [10]. If the conditions of pyrolysis are correctly optimized, the process can retain a high proportion of the $\mathrm{C}$ in the organic residue in a highly stabilized or inert form, so providing long term $\mathrm{C}$ sequestration in the soil. Different types of organic residues are better suited to anaerobic digestion and pyrolysis; the anaerobic digestion process requiring wet residues with a combined $\mathrm{C}: \mathrm{N}$ ratio of around $25[59,87]$, whereas pyrolysis requires dry $C$ rich residues. Therefore a combined approach allows a wider range of organic residues to be recycled. This also provides two different forms of energy to the household; these may be better suited to different cooking requirements and one form of energy provides backup when the other runs short. We therefore recommend that optimum management of organic residues for carbon sequestration should include a combination of pyrolysis of dry, $C$ rich materials to maximize $C$ sequestration from the organic residues, together with anaerobic digestion of wet, nutrient rich material to retain the nutrients needed for crop production, so increasing $\mathrm{C}$ sequestration from plant residues.

\section{Acknowledgements}

We are very grateful to the UK Department for International Development (DFID) New and Emerging Technologies Research Call for funding this work. PS is a Royal Society-Wolfson Research Merit Award holder.

\section{REFERENCES}

[1] Lal R, Soil carbon sequestration impacts on global climate change and food security. Science 2004;303(5677):1623-7.

[2] Aune JA, Lal R, Agricultural productivity in the tropics and critical limits of properties of Oxisols, Ultisols, and Alfisols. Trop Agr 1997;74(2):96-103.

[3] Nyamangara J. Soil organic matter status in Southern Africa in relation to sustainable soil tillage and crop production. In: Chuma E (ed) African Conservation Tillage Network Year Book. Harare, Zimbabwe:IES-GTZ;2002.pp.44-50.

[4] Assefa Abegaz, van Keulen $H$. Modelling soil nutrient dynamics under alternative farm management practices in the Northern Highlands of Ethiopia. Soil Till Res 2009;103(2):203-15.

[5] Troschinetz AM, Mihelcic JR. Sustainable recycling of municipal solid waste in developing countries. Waste Manage 2009;29(2):915-23.

[6] Boko M, Niang I, Nyong A, Vogel C. Africa. In: Parry ML, Canziani OF, Palutikof JP, van der Linden PJ, Hanson CE, editors. Climate Change 2007: Impacts, adaptation and vulnerability. Contribution of Working Group II to the Fourth Assessment Report of the Intergovernmental Panel on Climate Change, Cambridge UK; 2007, p. 433-67.

[7] Solomon S, Qin D, Manning M, Chen Z, Marquis M, Averyt KB, et al. IPCC. WGI. Climate Change The Physical Science Basis, Cambridge, UK: Cambridge University Press; 2007.

[8] Brohan P, Kennedy JJ, Harris I, Tett SFB, Jones PD. Uncertainty estimates in regional and global observed temperature changes: A new data set from 1850. J Geophys Res 2006;111(D12):12106. 
[9] Subedi M, Abegaz A, Balana B, Matthews R, Smith J. Can biogas digesters help to reduce deforestation in Sub-Saharan Africa? Biomass Bioenergy 2012 (this issue).

[10] Smith J, Abegaz A, Matthews R, Subedi M, Orskov R, Tumwesige V, et al. What is the potential for biogas digesters to improve soil fertility and crop production in Sub-Saharan Africa? Biomass Bioenergy 2012 (this issue).

[11] Smith J, Coleman K, Gottschalk P, Bellarby J, Richards M, Nayak D, et al. Estimating changes in national soil carbon stocks using ECOSSE - a new model that includes upland organic soils. Part I. Model description and uncertainty in national scale simulations of Scotland. Climate Res 2010;45(1):179-92.

[12] Gottschalk P, Smith JU, Wattenbach M, Bellarby J, Stehfest E, Arnell N, et al. How will organic carbon stocks in mineral soils evolve under future climate? Global projections using RothC for a range of climate change scenarios. Biogeosciences Discuss 2012;9(8):411-51.

[13] Assefa Abegaz, van Keulen $\mathrm{H}$, Mitiku Haile, Oosting SJ. Nutrient dynamics on smallholder farms in Teghane, Northern Highlands of Ethiopia. In: Bationo A, Waswa B, Kihara J, Kimetu J, editors. Advances in integrated soil fertility management in Sub-Saharan Africa: challenges and opportunities, Netherlands: Springer; 2007, pp. 365-78.

[14] Assefa Abegaz, Van Keulen H, Oosting SJ. Feed resources, livestock production and soil carbon dynamics in Teghane, Northern Highlands of Ethiopia. J Agr Sys 2007;94(2):391-404.

[15] Woods J, Hall DO. Bioenergy for Development, FAO Environment and Energy, Pap. 13. Rome: FAO - Food and Agriculture Organization of the United Nations;1994.

[16] Kakudidi EK. A study of plant materials used for house construction around Kibale National Park, western Uganda. Afr J Ecol 2007;45(1):22-7.

[17] Bernal MP, Sanchez-Monedero MA, Paredes C, Roig A. Carbon mineralization from organic wastes at different composting stages during their incubation with soil. Agr Ecosyst Environ 1998;69(3):175-89.

[18] Kirchmann H, Witter E. Composition of fresh, aerobic and anaerobic farm animal dungs. Bioresource Technol 1992;40(2):137-42.

[19] Graber ER, Hadas E. Potential energy generation and carbon savings from waste biomass pyrolysis in Israel. Ann Environ Sci 2009;3:207-16.

[20] Mohan D, Pittman CU, Steele PH. Pyrolysis of wood/biomass for bio-oil: a critical review. Energ Fuel 2006; 20(3):848-89.

[21] Preston CM, Schmidt MWI. Black (pyrogenic) carbon: a synthesis of current knowledge and uncertainties with special consideration of boreal regions. Biogeosciences 2006;3(4):397-420.

[22] Atkinson CJ, Fitzgerald JD, Hipps NA. Potential mechanisms for achieving agricultural benefits from biochar application to temperate soils: a review. Plant Soil 2010;337(1-2):1-18.

[23] Parton WJ, Stewart JWB, Cole CV. Dynamics of C, N, P and S in grassland soils: a model. Biogeochemistry 1988;5(1):109-31.

[24] Smith JU, Smith P, Wattenbach M, Zaehle S, Hiederer R, Jones RJA, et al. Projected changes in mineral soil carbon of European croplands and grasslands, 1990-2080. Global Change Biol 2005;11(12):2141-52.

[25] Bosatta E, Agren Gl. Dynamics of carbon and nitrogen in the organic matter of the soil: A generic theory. Am Nat 1991;138(1):227-45.

[26] Coleman K, Jenkinson DS. RothC-26.3. A model for the turnover of carbon in soil. In: Powlson DS, Smith P, Smith JU, editors. Evaluation of soil organic matter models using existing longterm datasets. NATO ASI Series I, Vol 38. Springer, Berlin; 1996, p. 237-46.

[27] Mason IG. Mathematical modelling of the composting process: a review. Waste Manage 2006;26(1):3-21.

[28] Tremier A, de Guardia A, Massiani C, Paul E, Martel JL. A respirometric method for characterising the organic composition and biodegradation kinetics and the temperature influence on the biodegradation kinetics, for a mixture of sludge and bulking agent to be cocomposted. Bioresource Technol 2005;96(2):169-80.

[29] Sole-Mauri F, Illa J, Magri A, Prenafeta-Boldu FX, Flotats X. An integrated biochemical and physical model for the composting process. Bioresource Technol 2007;98(17):3278-93.

[30] Zhang Y, Lashermes G, Houot S, Doublet J, Steyer JP, Zhu YG, et al. Modelling of organic matter dynamics during the composting process. Waste Manage 2012:32(1);19-30.

[31] Sinha MK, Sinha DP, Sinha H. Organic matter transformations in soils. V. Kinetics of carbon and nitrogen mineralization in soil amended with different organic materials. Plant Soil 1977;46(3):579-90.

[32] Boyle M, Paul EA. Carbon and nitrogen mineralization kinetics in soil previously amended with sewage sludge. Soil Sci Soc Am J 1989;53(3):99-103. 
[33] Murwira HK, Kirchmann H, Swift MJ. The effect of moisture on the decomposition rate of cattle manure. Plant Soil 1990;122(2):197-9.

[34] Ajwa HA, Tabatabai MA. Decomposition of different organic materials in soils. Biol Fert Soils 1994;18(3):175-82.

[35] Bernal MP, Kirchmann H. Carbon and nitrogen mineralization and ammonia volatilization from fresh, aerobically and anaerobically treated pig manure during incubation with soil. Biol Fertil Soils 1992;13(3):135-41.

[36] Massé DI, Droste RL. Comprehensive model of anaerobic digestion of swine manure slurry in a sequencing batch reactor. Water Res 2000;34(12):3087-106.

[37] Donoso-Bravo A, Mailier J, Martin C, Rodríguez G, Arturo Aceves-Lara C, Van de Wouwer A. Model selection, identification and validation in anaerobic digestion: A review. Water Res 2011;45(17):5347-64.

[38] Mata-Alvarez J, Macé S, Llabrés, P. Anaerobic digestion of organic solid wastes. An overview of research achievements and perspectives. Bioresource Technol 2000;74(1):3-16.

[39] Gaudy AF, Gaudy ET. Microbiology for Environmental Scientists and Engineers. Toronto: McGraw-Hill; 1980.

[40] Zinder SH. Microbiology and anaerobic conversion of organic wastes to methane: recent developments. ASM News 1984;50:294-8.

[41] Smith MR, Zinder SH, Mah RA. Microbial methanogenesis from acetate. Process Biochem 1980;15(4):34-9.

[42] Hill DT, Barth CL. A dynamic model for simulation of animal waste digestion. J Water Pollut Con F 1977;49(10):2129-43.

[43] Speece RE. Anaerobic Biotechnology: For Industrial Wastewater. Archae Press, 5840 R. E. Lee Drive, Nashville, TN 37215, 615-665-0847;1996.

[44] Eastman JA, Ferguson JF. Solubilization of particulate organic-carbon during the acid phase of anaerobic digestion. J Water Pollut Con F 1981;53(3):352-66.

[45] Andrews JF, Graef SP. Dynamic modeling and simulation of the anaerobic digestion process. In:Gould RF, editor. Advances in Chemistry Series. New York: American Chemical Society; 1971:126-62 (ACS Symposium Series; vol 105)

[46] Hill DT. A comprehensive dynamic model for animal waste methanogenesis. T ASAE 1982;25(5):1374-80.

[47] Mosey FE. Mathematical modelling of the anaerobic digestion process: regulatory mechanism for the formation of short-chain volatile acids from glucose. Water Sci Technol 1983;15(89):209-32.

[48] Harper SR, Pohland FG. Recent developments in hydrogen management during anaerobic biological wastewater treatment. Biotechnol Bioeng 1986;28(4):585-602.

[49] Rozzi A, Merlini S, Passino R. Development of a four population model of the anaerobic degradation of carbohydrates. Environ Technol Lett 1985;6(12):610-9.

[50] Jones RM, Hall ER. Assessment of dynamic models for high rate anaerobic treatment process. Environ Technol Lett 1989;10(6):551-66.

[51] Costello DJ, Greenfield PF, Lee PL. Dynamic modelling of a single-stage high-rate anaerobic reactor-I. Model derivation. Water Res 1991;25(7):847-58.

[52] Batstone DJ, Keller J, Angelidaki I, Kalyuzhnyi SV, Pavlostathis SG, Rozzi A, et al. Anaerobic Digestion Model No. 1. (ADM1). IWA Task Group for Mathematical Modelling of Anaerobic Digestion Processes, London: IWA Publishing; 2002.

[53] Hammes K, Torn MS, Lapenas AG, Schmidt MWI. Centennial turnover observed in a Russian steppe soil. Biogeosciences 2008;5(5):1339-50.

[54] Nguyen BT, Lehmann J, Kinyangi J, Smernik R, Riha SJ, Engelhard MH. Long-term black carbon dynamics in cultivated soil. Biogeochemistry 2009;92(1-2):163-76.

[55] Foereid B, Lehmann J, Major J. Modeling black carbon degradation and movement in soil. Plant Soil 2011;345(1-2):223-36.

[56] Ciavatta C, Govi M, Pasotti L, Sequi P. Changes in organic matter during stabilization of compost from municipal solid wastes, Bioresource Technol 1993;43(2):141.

[57] Beck-Friis B, Smårs S, Jönsson H, Kirchmann H 2001. Gaseous emissions of carbon dioxide, ammonia and nitrous oxide from organic household waste in a compost reactor under different temperature regimes. J Agr Eng Res 2001;78(4):423-30.

[58] Massé DI, Croteau F, Massé L. The fate of crop nutrients during digestion of swine manure in psychrophilic anaerobic sequencing batch reactors. Bioresource Technol 2007;98(15):2819-23.

[59] Schievano A, D'Imporzano G, Salati S, Adani F. On-field study of anaerobic digestion full-scale plants (Part I): An on-field methodology to determine mass, carbon and nutrients balance. 
Bioresource Technol 2011;102(17):7737-44.

[60] Perez M, Rodriguez-Cano R, Romero LI, Sales D. Anaerobic thermophilic digestion of cutting oil wastewater: effect of co-substrate. Biochem Eng J 2006;29(3):250-7.

[61] Messner $\mathrm{H}$, Amberger A. Composition, nitrification and fertilizing effect of anaerobically fermented slurry. In: Szabolcs I, Welte E (editors). Agricultural Waste Management and Environmental Protection: 4th International CIEC Symposium, Braunschweig, Germany: CIEC; 1987, p. 125-30.

[62] Mechanical Wood Products Branch. Industrial charcoal making, FAO Forestry Research Paper 63. Rome: FAO - Food and Agriculture Organization of the United Nations;1985.

[63] Daud WMAW, Ali WSW, Sulaiman MZ. Effect of carbonization temperature on the yield and porosity of char produced from palm shell. J Chem Technol Biot 2001;76(12):1281-5.

[64] Demirbas A. Carbonization ranking of selected biomass for charcoal, liquid and gaseous products. Energ Convers Manage 2001; 42(10):1229-38.

[65] Baldock JA, Smernik RJ. Chemical composition and bioavailability of thermally altered Pinus resinosa (Red pine) wood. Org Geochem 2002;33(9):1093-109.

[66] Laird DA. The charcoal vision: a win-win-win scenario for simultaneously producing bio-energy, permanently sequestering carbon, while improving soil and water quality. Agron J. 2008;100(1):178-81.

[67] Downie A, Crosky A, Munroe P. Physical properties of biochar. Chapter 2. In: Lehmann J, Joseph S, editors. Biochar for environmental management science and technology, London. Earthscan; 2009, p.13-32.

[68] Bruun EW, Hauggaard-Nielsen H, Ibrahim N, Egsgaard H, Ambus P, Jensen PA, et al. Influence of fast pyrolysis temperature on biochar labile fraction and short-term carbon loss in a loamy soil. Biomass Bioenergy 2011;35(3):1182-9.

[69] Yang H, Yan R, Chen H, Lee D, Zheng C. Characteristics of hemicellulose, cellulose and lignin pyrolysis. Fuel 2007;86(12-13):1781-8.

[70] Marstorp H. Influence of soluble carbohydrates, free amino acids, and protein content on the decomposition of Lolium multiflorum shoots. Biol Fert Soils 1996;21(4):257-63.

[71] Francou C, Linères $M$, Derenne $S$, Le Villio-Poitrenaud M, Houot $S$. Influence of green waste, biowaste and paper-cardboard initial ratios on organic matter transformations during composting. Bioresource Technol 2008;99(18):8926-34.

[72] Doublet J, Francou C, Poitrenaud M, Houot S. Influence of bulking agents on organic matter evolution during sewage sludge composting; consequences on compost organic matter stability and $\mathrm{N}$ availability. Bioresource Technol 2011;102(2):1298-307.

[73] Cheneby D, Nicolardot B. Use of mineralization kinetics to estimate the agricultural value of organic fertilizers. In:Jackson DV, Merillot JM, L'Hermite P, editors. Composting and Compost Quality Assurance Criteria. Luxembourg: Commission of the European Community; 1992, p.188-95.

[74] Serra-Wittling C, Houot S, Barriuso E. Soil enzymatic response to addition of municipal solidwaste compost. Biol Fert Soils 1995;20(4):226-36.

[75] Marcato C-E, Mohtar R, Revel J-C, Pouech P, Hafidi M, Guiresse M. Impact of anaerobic digestion on organic matter quality in pig slurry. Int Biodeter Biodegr 2009;63(3):260-6.

[76] García-Gómez A, Bernal MP, Roig A. Carbon mineralisation and plant growth in soil amended with compost samples at different degrees of maturity. Waste Manage Res 2003;21(2):161-71.

[77] Smidt E, Lechner P, Schwanninger M, Haberhauer G, Gerzabek MH. Characterization of waste organic matter by FT-IR spectroscopy: application in waste science. Appl Spectrosc 2002;56(9):1170-5.

[78] Ponsá S, Gea T, Alerm L, Cerezo J, Sánchez A. Comparison of aerobic and anaerobic stability indices through a MSW biological treatment process. Waste Manage 2008;28(12):2735-42.

[79] Kuhlbusch TAJ, Andreae MO, Cachier H, Goldammer JG, Lacaux JP, Shea R, et al. Black carbon formation by savanna fires: measurements and implication for the global carbon cycle. J Geophys Res Atmos 1996;101(D19):23651-65.

[80] Dai X, Boutton TW, Glaser B, Ansley RJ, Zech W. Black carbon in temperate mixed-grass savanna. Soil Biol Biochem 2005;37(10):1879-81.

[81] Wardle DA, Nilsson M-C, Zackrisson O. Fire-derived charcoal causes loss of forest humus. Science 2008;320(5876):629.

[82] Cheng C-H, Lehmann J, Thies JE, Burton SD. Stability of black carbon in soils across a climatic gradient. J Geophys Res 2008;113:G02027.

[83] Cheng $\mathrm{C}-\mathrm{H}$, Lehmann J. Ageing of black carbon along a temperature gradient. Chemosphere 2009;75(8):1021-7. 
[84] Nguyen BT, Lehmann J. Black carbon decomposition under varying water regimes. Org Geochem 2009;40(8):846-53.

[85] Lehmann J, Rondon MA. Bio-char soil management on highly weathered soil in the humid tropics'. Chapter 36. In: Uphoff N, editor. Biological approaches to sustainable soil systems, Boca Raton. CRC; 2005, p. 517-30.

[86] Cross A, Sohi SP. The priming potential of biochar products in relation to labile carbon contents and soil organic matter status. Soil Biol Biochem 2011;43(10):2127-34.

[87] De Bertoldi M, Vallini G, Pera A. The biology of composting: a review. Waste Manag Res 1983;1(1):157-76. 


\section{Figures}

Fig. 1 - Temperature sensitivity of carbon sequestration following incorporation of $1 \mathrm{tha}^{-1} \mathrm{y}^{-1}$ of carbon in differently treated organic residues. Assumes annual incorporation continues until steady state is reached (300 years)

Fig. 2 - Moisture sensitivity of carbon sequestration following incorporation of $1 \mathrm{tha}^{-1} \mathrm{y}^{-1}$ of carbon in differently treated organic residues. Assumes annual incorporation continues until steady state is reached (300 years)

Fig. 3 - Sensitivity of carbon sequestration to percent clay following incorporation of $1 \mathrm{tha}^{-1} \mathrm{y}^{-1}$ of carbon in differently treated organic residues. Assumes annual incorporation continues until steady state is reached (300 years)

Fig. 4 - Temperature sensitivity of carbon sequestration following incorporation of differently treated organic residues derived from $1 \mathrm{t} \mathrm{ha}^{-1} \mathrm{y}^{-1}$ of carbon in fresh residue. Assumes annual incorporation continues until steady state is reached (300 years)

Fig. 5 - Moisture sensitivity of carbon sequestration following incorporation of differently treated organic residues derived from $1 \mathrm{t} \mathrm{ha}^{-1} \mathrm{y}^{-1}$ of carbon in fresh residue. Assumes annual incorporation continues until steady state is reached (300 years)

Fig. 6 - Sensitivity of carbon sequestration to percent clay following incorporation of differently treated organic residues derived from $1 \mathrm{t} \mathrm{ha}^{-1} \mathrm{y}^{-1}$ of carbon in fresh residue. Assumes annual incorporation continues until steady state is reached (300 years)

Fig. 7 - Uncertainty in carbon sequestration for differently treated organic residues derived from $1 \mathrm{t}$ $\mathrm{ha}^{-1} \mathrm{y}^{-1}$ of carbon in fresh residue

Fig. 8 - Uncertainty in carbon sequestration introduced by inputs describing quality of material and the impacts of treatment for differently treated organic residues

Fig. 9 - Rate of carbon sequestration for application continued over 20 years of differently treated organic residues derived from $1 \mathrm{tha}^{-1} \mathrm{y}^{-1}$ of carbon in fresh residue 
Fig. 1 - Temperature sensitivity of carbon sequestration following incorporation of $1 \mathrm{tha}^{-1} \mathrm{y}^{-1}$ of $C$ in differently treated organic residues. Assumes annual incorporation continues until steady state is reached (300 years)

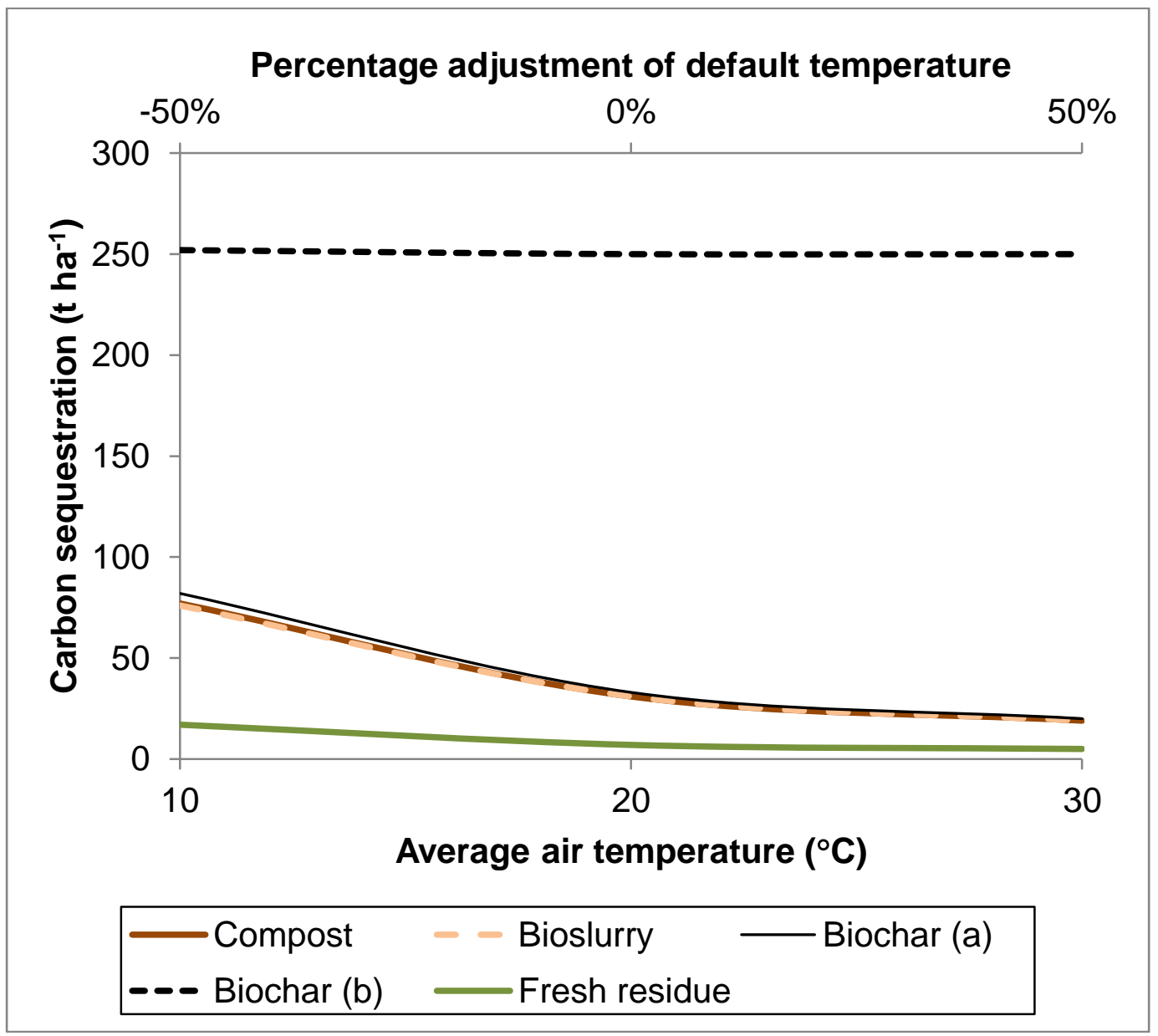


Fig. 2 - Moisture sensitivity of carbon sequestration following incorporation of $1 \mathrm{t} \mathrm{ha}^{-1} \mathrm{y}^{-1}$ of carbon in differently treated organic residues. Assumes annual incorporation continues until steady state is reached ( 300 years)




Fig. 3 - Sensitivity of carbon sequestration to percent clay following incorporation of $1 \mathrm{tha}^{-1} \mathrm{y}^{-1}$ of carbon in differently treated organic residues. Assumes annual incorporation continues until steady state is reached (300 years)

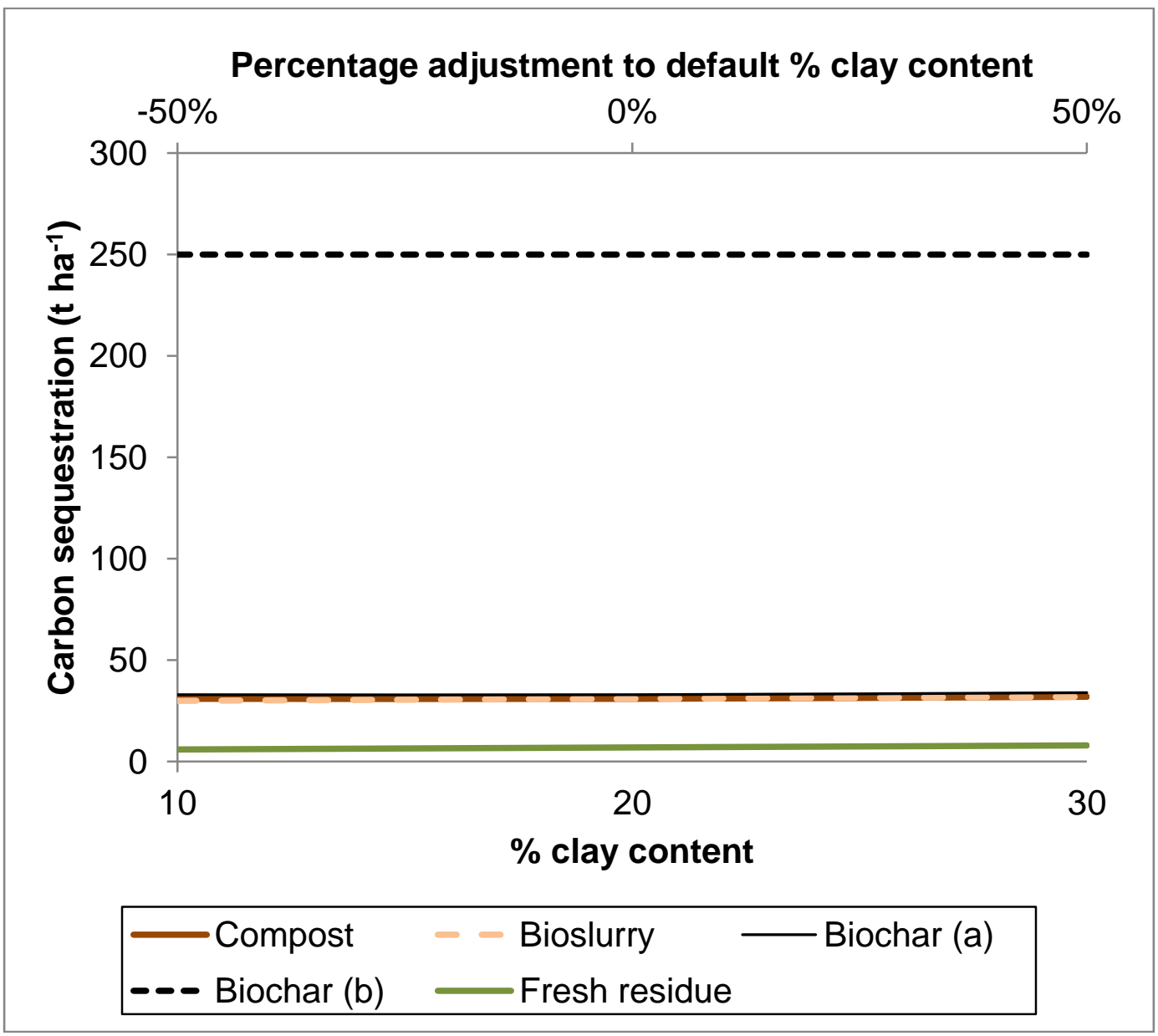


Fig. 4 - Temperature sensitivity of carbon sequestration following incorporation of differently treated organic residues derived from $1 \mathrm{t} \mathrm{ha}^{-1} \mathrm{y}^{-1}$ of carbon in fresh residue. Assumes annual incorporation continues until steady state is reached (300 years)

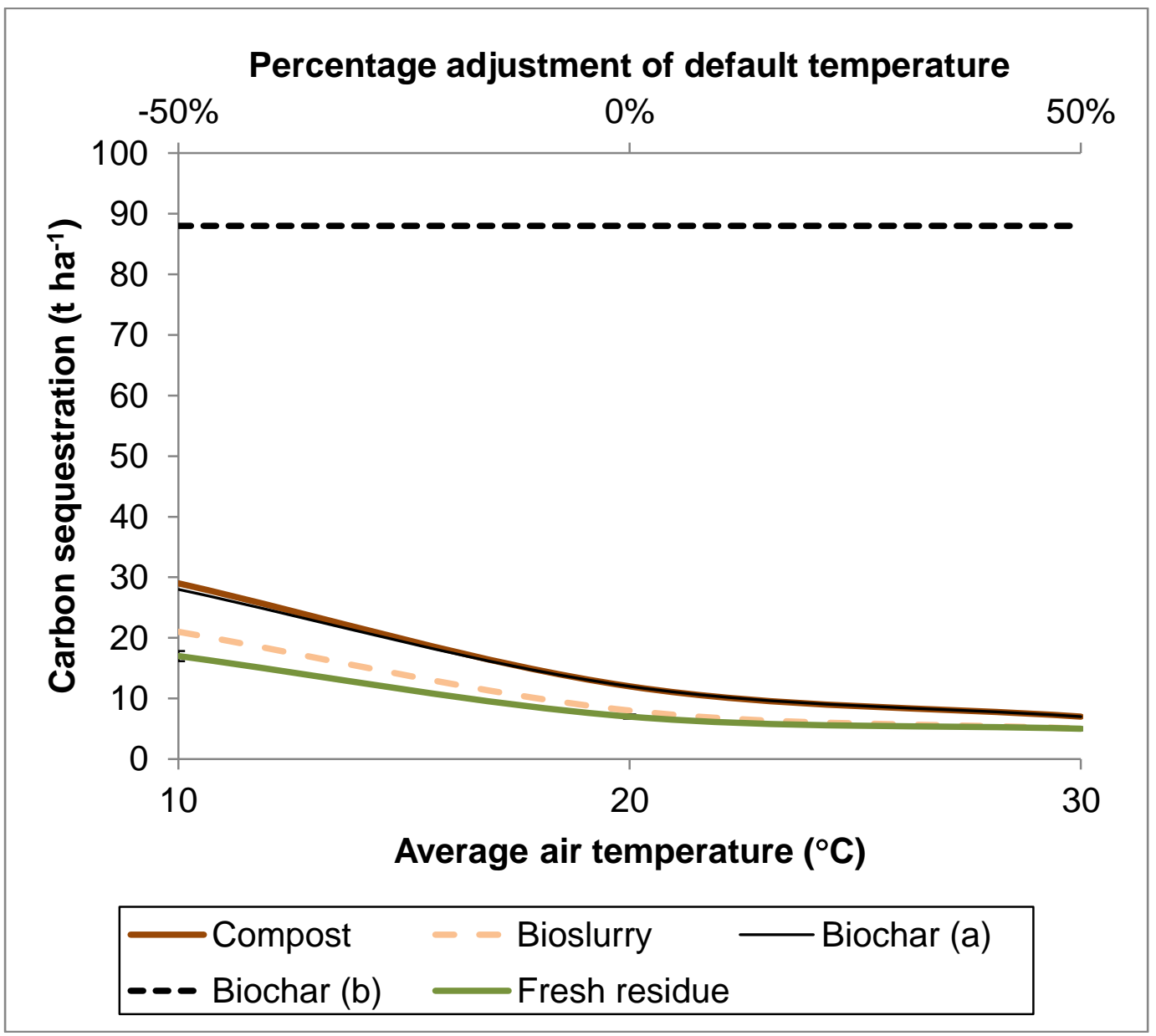


Fig. 5 - Moisture sensitivity of carbon sequestration following incorporation of differently treated organic residues derived from $1 \mathrm{t} \mathrm{ha}^{-1} \mathrm{y}^{-1}$ of carbon in fresh residue. Assumes annual incorporation continues until steady state is reached (300 years)

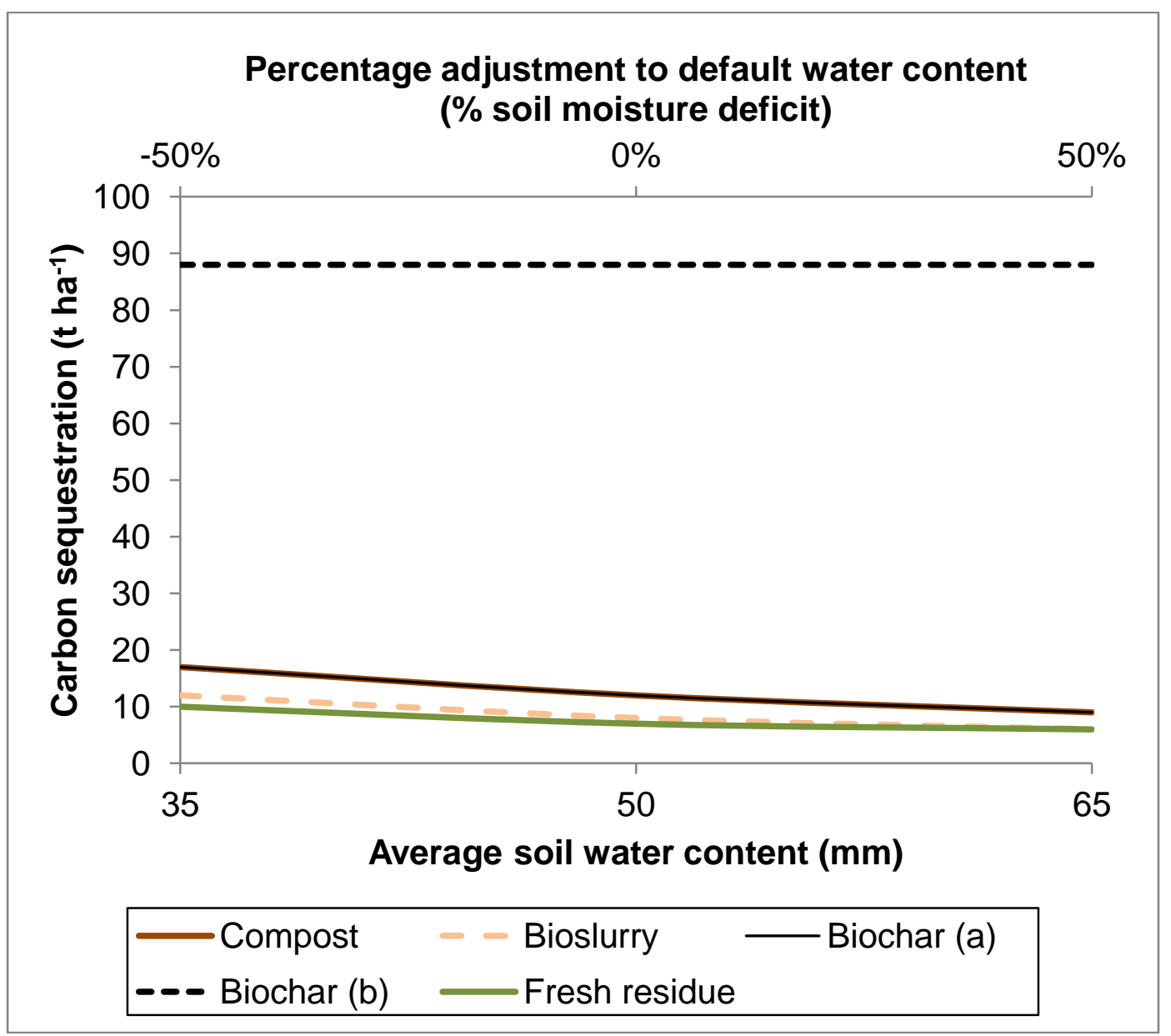


Fig. 6 - Sensitivity of carbon sequestration to percent clay following incorporation of differently treated organic residues derived from $1 \mathrm{t} \mathrm{ha}^{-1} \mathrm{y}^{-1}$ of carbon in fresh residue. Assumes annual incorporation continues until steady state is reached (300 years)

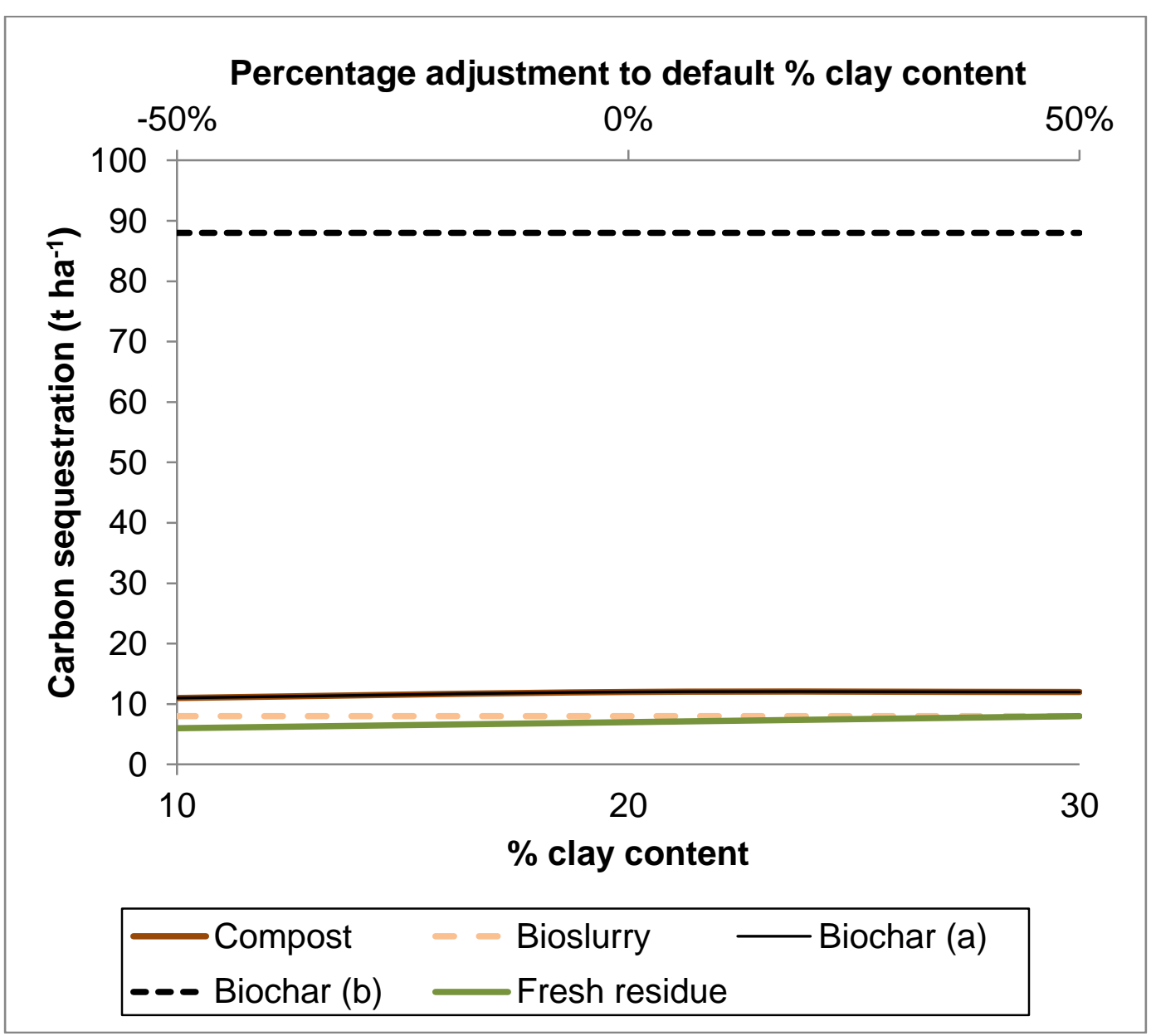


Fig. 7 - Uncertainty in carbon sequestration for differently treated organic residues derived from $1 \mathrm{t}$ $\mathrm{ha}^{-1} \mathrm{y}^{-1}$ of carbon in fresh residue

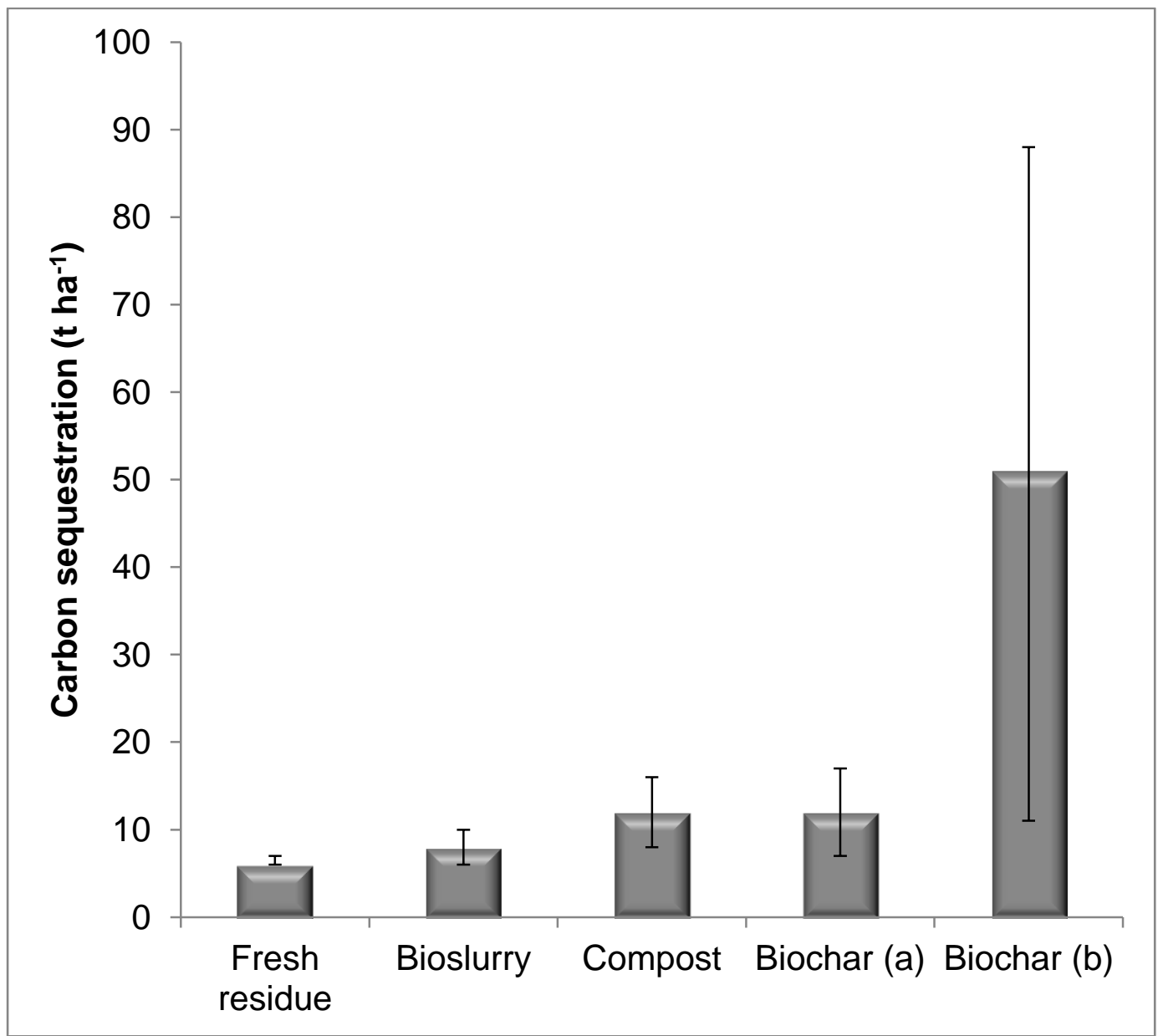


Fig. 8 - Uncertainty in carbon sequestration introduced by inputs describing quality of material and the impacts of treatment for differently treated organic residues

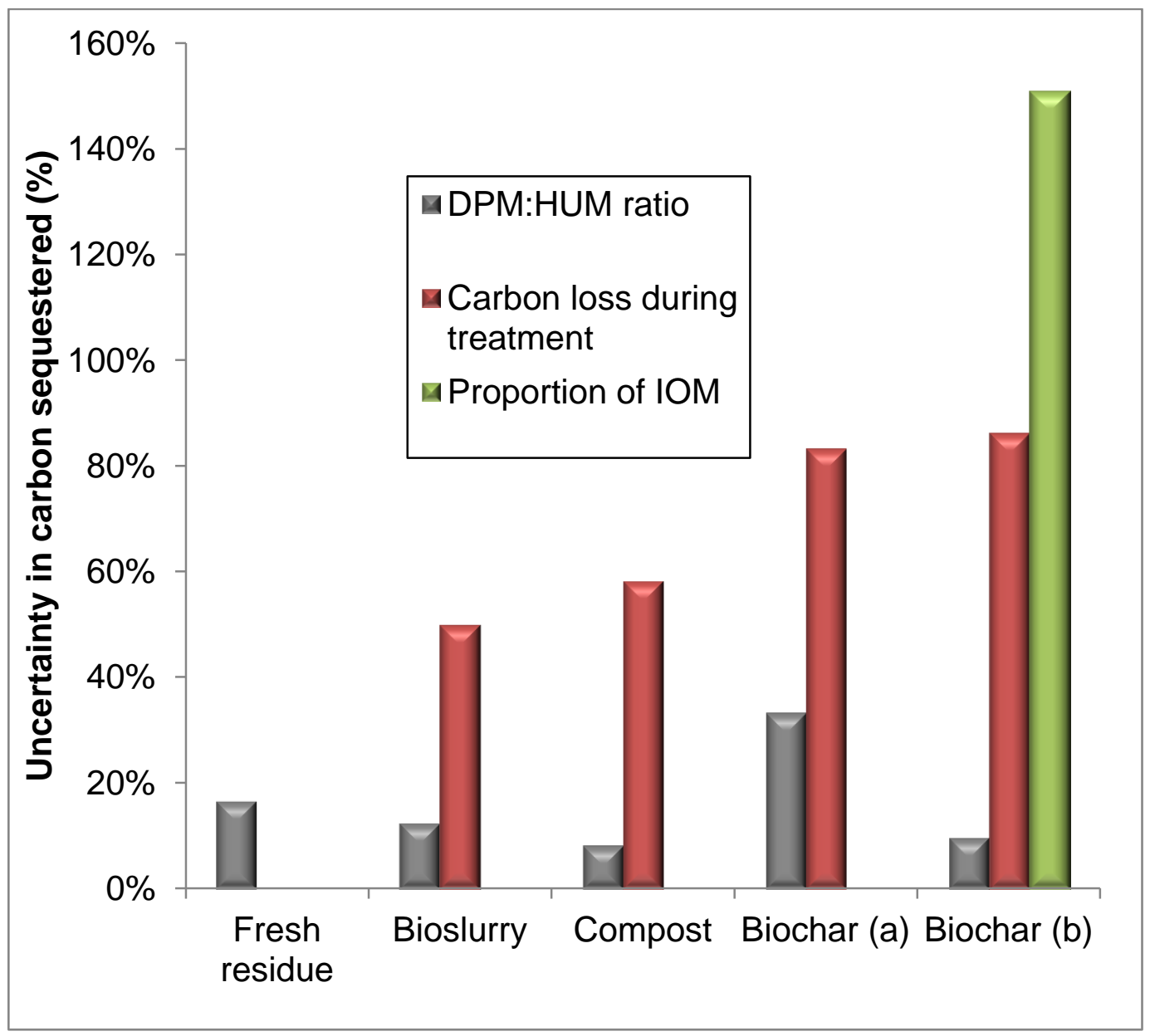


Fig. 9 - Rate of carbon sequestration for application continued over 20 years of differently treated organic residues derived from $1 \mathrm{tha}^{-1} \mathrm{y}^{-1}$ of carbon in fresh residue

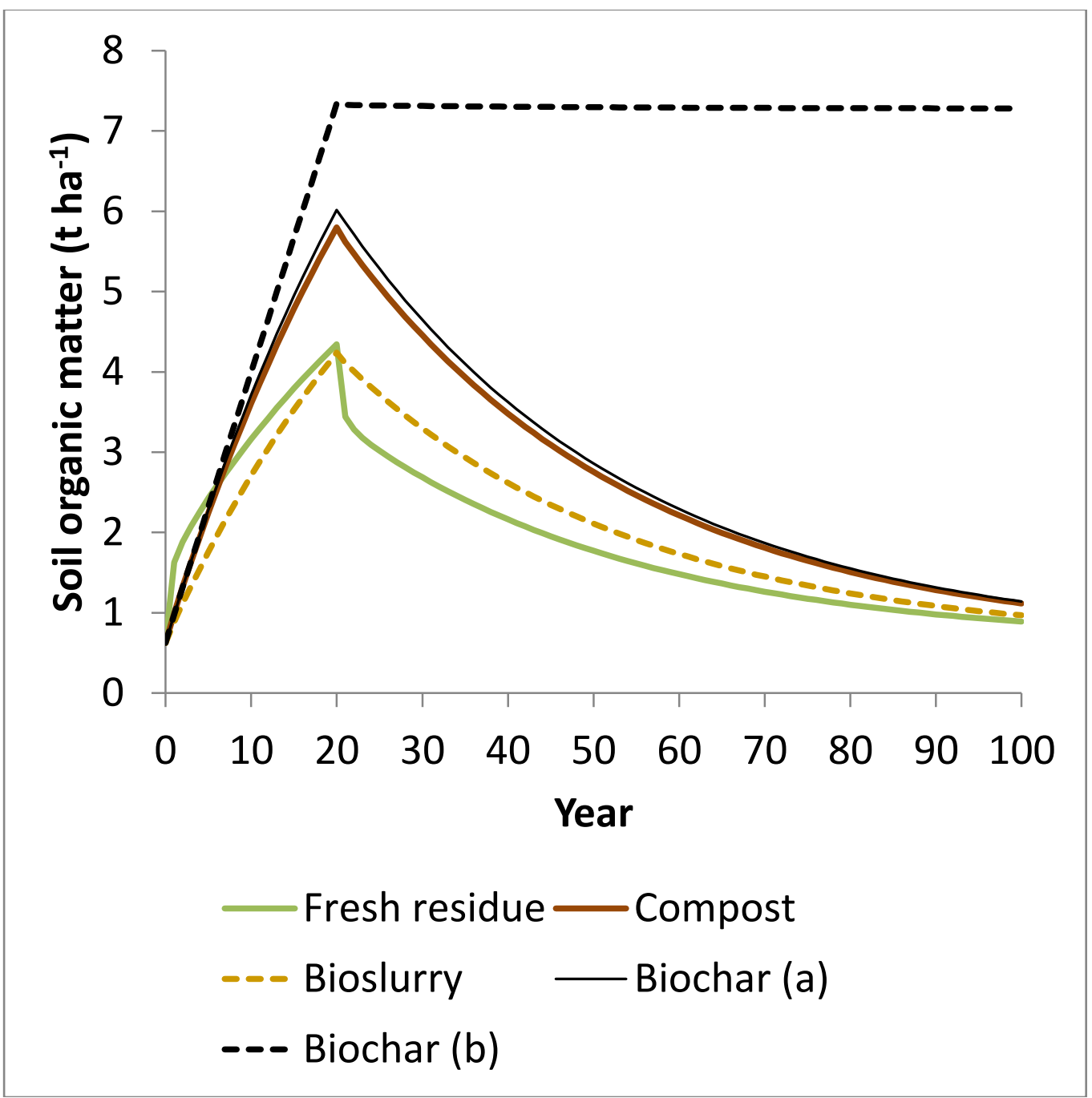




\section{Tables}

Table 1 - Relative inputs of treated and untreated organic residues used in example simulations of $\mathrm{C}$ sequestration in soil

Table 2 - The decomposability of treated and untreated organic residues at $28{ }^{\circ} \mathrm{C}$ and with water content maintained at $60 \%$ of field capacity

Table 3 - Input values used in simulation of $\mathrm{C}$ sequestered by incorporation of differently treated organic residues using the RothC model

Table 4 - Description of different classes of treated and untreated organic residue used in RothC simulations 
Table 1 - Relative inputs of treated and untreated organic residues used in example simulations of $C$ sequestration in soil

\begin{tabular}{lcc}
\hline Organic residue & C loss during treatment (\%) & $\begin{array}{c}\text { Annual C inputs as a } \\
\text { percent of the untreated } \\
\text { organic residue (\%) }\end{array}$ \\
\hline $\begin{array}{l}\text { Untreated } \\
\text { Compost [17] }\end{array}$ & $0 \%$ & $100 \%$ \\
$\quad$ Mean & & \\
Minimum & $63 \%$ & $37 \%$ \\
$\quad$ Maximum & $74 \%$ & $26 \%$ \\
Bioslurry [59] & $52 \%$ & $48 \%$ \\
$\quad$ Mean & & \\
Minimum & $75 \%$ & $26 \%$ \\
Maximum & $80 \%$ & $20 \%$ \\
Biochar [68] & $69 \%$ & $31 \%$ \\
Mean & & \\
Minimum & $65 \%$ & $35 \%$ \\
Maximum & $80 \%$ & $20 \%$ \\
\hline
\end{tabular}


Table 2 - The decomposability of treated and untreated organic residues at $28{ }^{\circ} \mathrm{C}$ and with water content maintained at $60 \%$ of field capacity

\begin{tabular}{|c|c|c|c|c|c|c|c|}
\hline Organic residue & $\begin{array}{l}\% \\
\text { organic } \\
\text { residue } \\
\text { lost }\end{array}$ & $\begin{array}{l}\text { Duration of } \\
\text { incubation } \\
\text { (days) }\end{array}$ & $\begin{array}{l}{ }^{a} \text { Proportion of } \mathrm{C} \text { in } \\
\text { DPM lost during } \\
\text { incubation }\left(\mathrm{t} \mathrm{t}^{-1}\right)\end{array}$ & $\begin{array}{l}\text { b Proportion of } \mathrm{C} \text { in } \\
\text { HUM lost during } \\
\text { incubation }\left(\mathrm{t} \mathrm{t}^{-1}\right)\end{array}$ & $\begin{array}{c}\text { Proportion of } \\
\mathrm{C} \text { in organic } \\
\text { residue as } \\
\text { DPM } \\
\left(\mathrm{t} \mathrm{t}^{-1}\right)\end{array}$ & $\begin{array}{c}\text { Proportion of } \\
\mathrm{C} \text { in organic } \\
\text { residue as } \\
\text { HUM } \\
\left(\mathrm{t} \mathrm{t}^{-1}\right)\end{array}$ & $\begin{array}{l}\text { DPM/HUM } \\
\text { ratio }\end{array}$ \\
\hline \multicolumn{8}{|l|}{ Untreated [17] } \\
\hline Mean & 97 & 140 & 1.00 & 0.03 & 0.97 & 0.03 & 31.45 \\
\hline Minimum & 95 & 140 & 1.00 & 0.03 & 0.95 & 0.05 & 18.47 \\
\hline Maximum & 99 & 140 & 1.00 & 0.03 & 0.99 & 0.01 & 96.37 \\
\hline \multicolumn{8}{|l|}{ Untreated [17] } \\
\hline Mean & 41.5 & 30 & 0.94 & 0.01 & 0.44 & 0.56 & 0.77 \\
\hline Minimum & 21 & 30 & 0.94 & 0.01 & 0.22 & 0.78 & 0.28 \\
\hline Maximum & 62 & 30 & 0.94 & 0.01 & 0.66 & 0.34 & 1.90 \\
\hline \multicolumn{8}{|l|}{ Compost [17] } \\
\hline Mean & 9 & 140 & 1.00 & 0.03 & 0.07 & 0.93 & 0.07 \\
\hline Minimum & 6 & 140 & 1.00 & 0.03 & 0.03 & 0.97 & 0.04 \\
\hline Maximum & 12 & 140 & 1.00 & 0.03 & 0.10 & 0.90 & 0.11 \\
\hline \multicolumn{8}{|l|}{ Untreated [75] } \\
\hline Mean & 17.6 & 49 & 0.99 & 0.01 & 0.17 & 0.83 & 0.20 \\
\hline \multicolumn{8}{|l|}{ Compost [75] } \\
\hline Mean & 12 & 49 & 0.99 & 0.01 & 0.11 & 0.89 & 0.13 \\
\hline \multicolumn{8}{|l|}{ Bioslurry [75] } \\
\hline Mean & 12 & 28 & 0.93 & 0.01 & 0.12 & 0.88 & 0.14 \\
\hline \multicolumn{8}{|l|}{ Biochar [68] } \\
\hline Mean & 7.5 & 140 & 1.00 & 0.03 & 0.05 & 0.95 & 0.05 \\
\hline Minimum & 3 & 140 & 1.00 & 0.03 & 0.00 & 1.00 & 0.00 \\
\hline Maximum & 12 & 140 & 1.00 & 0.03 & 0.10 & 0.90 & 0.11 \\
\hline \multirow[t]{2}{*}{ Notes: } & \multicolumn{5}{|c|}{${ }^{a}$ Rate constant for decomposition of DPM [26] } & 10 & $y^{-1}$ \\
\hline & \multicolumn{5}{|c|}{${ }^{\mathrm{b}}$ Rate constant for decomposition of HUM [26] } & 0.02 & $y^{-1}$ \\
\hline
\end{tabular}


1 Table 3 - Input values used in simulation of $\mathrm{C}$ sequestered by incorporation of differently treated 2 organic residues using the RothC model

3

\begin{tabular}{lc}
\hline Input variable & Value \\
\hline Average annual air temperature $\left({ }^{\circ} \mathrm{C}\right)$ & 20 \\
Average soil water content in $25 \mathrm{~cm}$ soil $(\mathrm{mm})$ & 50 \\
Mass fraction of clay $\left(\mathrm{g} \mathrm{kg}^{-1}\right.$ of dry soil) & 200 \\
Field capacity in $25 \mathrm{~cm}$ depth of soil $(\mathrm{mm})$ & 80 \\
Wilting point in $25 \mathrm{~cm}$ depth of soil $(\mathrm{mm})$ & 20 \\
Soil pH & 7 \\
Soil salinity (EC 1:5) & 0 \\
Extra organic input of C $\left(\mathrm{t} \mathrm{ha}^{-1}^{-1}\right)$ & 1 \\
Average DPM:RPM ratio of plant inputs & 1.44 \\
\hline
\end{tabular}


7 Table 4 - Description of different classes of treated and untreated organic residue used in RothC

8 simulations

9

\begin{tabular}{|c|c|c|c|c|c|c|c|c|c|}
\hline \multirow[t]{2}{*}{$\begin{array}{l}\text { Organic } \\
\text { residue }\end{array}$} & \multicolumn{3}{|c|}{$\begin{array}{c}\text { Annual } C \text { inputs as a percent } \\
\text { of the untreated organic } \\
\text { residue }(\%)\end{array}$} & \multicolumn{3}{|c|}{$\begin{array}{l}\text { Inert organic matter in } \\
\text { organic residue }(\%)\end{array}$} & \multicolumn{3}{|c|}{ DPM/HUM ratio } \\
\hline & Minimum & Average & Maximum & Minimum & Average & Maximum & Minimum & Average & Maximum \\
\hline $\begin{array}{l}\text { Fresh } \\
\text { residue }\end{array}$ & 100 & 100 & 100 & 0 & 0 & 0 & 18 & 32 & 96 \\
\hline Compost & 26 & 37 & 48 & 0 & 0 & 0 & 0.05 & 0.10 & 0.15 \\
\hline Bioslurry & 20 & 26 & 31 & 0 & 0 & 0 & 0.05 & 0.10 & 0.15 \\
\hline $\begin{array}{l}\text { Biochar } \\
\text { (a) }\end{array}$ & 20 & 35 & 50 & 0 & 0 & 0 & 0.004 & 0.057 & 0.11 \\
\hline $\begin{array}{l}\text { Biochar } \\
\text { (b) }\end{array}$ & 20 & 35 & 50 & 5 & 50 & 95 & 18 & 32 & 96 \\
\hline
\end{tabular}

10

11

12

13 


\section{Highlights}

- Application of bioslurry from biogas digesters is compared to other uses

- Applying bioslurry directly sequesters less carbon than applying biochar or compost

- Indirect carbon sequestration through plant inputs may be higher for bioslurry

- Use pyrolysis of dry, carbon rich waste to maximize direct carbon sequestration

- Use anaerobic digestion of wet, nutrient rich waste to sequester carbon from plants 